https://doi.org/10.15407/frg2020.03.208

UDC [633.11: 631.813] (631.559)

\title{
RADIATION USE EFFICIENCY OF WINTER WHEAT CANOPY DURING PRE-ANTHESIS GROWTH
}

\author{
G.O. PRIADKINA ${ }^{1}$, O.O. STASIK ${ }^{1}$, A.M. POLIOVYI ${ }^{2}$, O.E. YARMOLSKA ${ }^{2}$, \\ K. KUZMOVA ${ }^{3}$ \\ ${ }^{1}$ Institute of Plant Physiology and Genetics, National Academy of Sciences of Ukraine \\ 31/17 Vasylkivska Str., Kyiv, 03022, Ukraine \\ ${ }^{2}$ Odessa National Ecological University \\ 15 Lvivska Str., Odessa, 65016, Ukraine \\ ${ }^{3}$ Agricultural University \\ 12 Mendeleev Av., Plovdiv, 4000, Bulgaria \\ e-mail: galpryadk@gmail.com
}

The relationship between the photosynthetically active radiation use efficiency during the pre-anthesis period of ontogenesis and yield of winter wheat were studied in field experiments in years with dry weather conditions $(2018$ - during period of stem elongation-anthesis, 2019 - during the period of grain filling). The studies were conducted using 6 varieties of bread winter wheat (Triticum aestivum L.) originated from the Institute of Plant Physiology and Genetics, National Academy of Sciences of Ukraine. Variety Smuhlianka is widely used high-yielding variety released in 2004, while the others 5 varieties - Hospodarka, Kyivska 17, Pochaina, Krasnopilka and Poradnytsia are more recently released (2017-2018). It has been established that, starting from the booting stage (GS 45), varieties can be divided into 2 groups differing in leaf area index: varieties Hospodarka, Kyivska 17 and Pochaina were 15$30 \%$ superior than the varieties Krasnopilka, Smuhlianka and Poradnytsia. At the period from anthesis to milky-wax ripeness, the dry biomass growth rate in the first three varieties was also higher than in the last three. The radiation use efficiency (RUE) at the period of spring vegetation (stem elongation-booting) did not differ significantly between the varieties, whereas during the period booting-anthesis and anthesis-late milk ripeness, it was significantly higher in the varieties Hospodarka, Kyivska 17 and Pochaina than in other varieties. The first three varieties have also higher grain yield in both years: $8.60-8.72$ in 2018 and 9.15-9.78 t/ha in 2019, while in the varieties Krasnopilka, Smuhlianka and Poradnytsia yield varied in the range of 7.12-7.85 and 7.85-8.48 t/ha, respectively. A positive correlation was found between the RUE in certain periods of pre-anthesis development and grain yield, and the grain number per $1 \mathrm{~m}^{2}$, with the exception for the period of stem elongation-booting. The greater efficiency of converting light energy into biomass at the period before anthesis contributes to increasing wheat grain productivity that is associated with a higher rate of above-ground biomass accumulation at the period before flowering and larger number of grains per square meter of soil. These data supported suggestion that a higher RUE during the pre-anthesis growth period may be considered as an important determinant of high wheat productivity and may be used as a potential breeding criterion for high wheat productivity.

Key words: Triticum aestivum L., radiation use efficiency, pre-anthesis biomass accumulation, productivity.

Citation: Priadkina G.O., Stasik O.O., Poliovyi A.M., Yarmolska O.E., Kuzmova K. Radiation use efficiency of winter wheat canopy during pre-anthesis growth. Fiziol. rast. genet., 2020, 52, No. 3, pp. 208-223. https://doi.org/10.15407/frg2020.03.208 208 
The fact that energy-rich compounds are formed from carbon dioxide and water during photosynthesis using energy of photosynthetically active radiation (PAR, 380-700 nm), accentuate the relationship between plants productivity and their ability to absorb and convert solar radiation into chemical bonds energy for further use in metabolic processes. Thereby, one of the possibilities that can lead to increased productivity is supposed an increase in the absorption and convertion of solar radiation energy. The efficiency with which radiation can be absorbed by the canopy is determined by the plant growth rate, the assimilation surface area development, the time of soil full projective covering onset with vegetation, and the duration of the photosynthetic apparatus functitioning.

Monteith and Moss [1] showed that the potential grain yield per $1 \mathrm{~m}^{2}$ is determined by four main components: the incident photosynthetically active radiation coming to the top of the canopy during the growing season, fraction of intercepted radiation, radiation use efficiency (RUE) or the efficiency of energy conversion into biomass, as well as a ratio of economically valuable part versus total above-ground biomass - harvest index (HI).

Modern wheat varieties absorb a significant amount of incident radiation due to the high leaf area index (LAI). In particular at the reproductive period, they absorb up to $90 \%$ of the incoming solar radiation $[2,3]$. While for old winter wheat varieties, LAI over $4.5 \mathrm{~m}^{2}$ of green leaves per $1 \mathrm{~m}^{2}$ of soil led to a decline in solar energy use due to leaf shadowing [4], the modern high-yielding varieties with an erectoid flag leaves show optimum LAI at $6-7 \mathrm{~m}^{2} / \mathrm{m}^{2}[5,6]$. The HI of modern wheat varieties is also close to maximum. Since the Green Revolution HI has grown to $0.50-0.55$, which is slightly less than the maximum theoretical value -0.62 [7]. Therefore, one of the factors that can essentially contribute to increase in wheat yield remains the improving of RUE. Theoretical calculations reveal that wheat yield potential can be improved by up to $50 \%$ through the genetic improvement of RUE [8]. The limited capacity to increase HI highlights RUE as a factor that needs to be incorporated into further breeding programs.

It is known that RUE depends on the crops, conditions of the year, phenological stage, conditions of water supply, nitrogen nutrition, etc. [911]. Thus, it was found that drought significantly reduced the efficiency of energy conversion into biomass in various wheat varieties, compared with the irrigated control $[12,13]$. At the same time for semi-arid location of Delhi region in one of the seasons, wheat canopy RUE was higher under one of the irrigation regimes, however in the next season, no significant effect of irrigation on RUE was found under any of the regimes [10]. In this research, it was also shown that an increase in doses of nitrogen fertilizers (from $\mathrm{N}_{40}$ to $\mathrm{N}_{160}$ ) has improved RUE. We previously also found that wheat plants foliar treatment with a complex of 7 trace elements and its combined use with carbamide contributed to an increase in the efficiency of solar energy conversion into biomass [11].

The genetic differences between wheat varieties in the efficiency of energy conversion into biomass were established in several studies. It was shown RUE increase for wheat varieties released in United Kingdom at 
1990s, compared with varieties of the 1970-80s [14], and for Australian wheat varieties released between 1958 and 2007 [15]. The results of four field experiments, conducted on number of bred wheat varieties in the Mediterranean region of Spain, showed that after anthesis RUE in two oldest genotypes was significantly lower than in the other varieties [16]. The authors believed that lesser RUE in these old genotypes was associated with a smaller grains number per $\mathrm{m}^{2}$ than in modern varieties. It was assumed that RUE in old varieties decreased after anthesis due to the lack of assimilates sink demand [16].

However, the manifestation of RUE genetic variation in wheat may depends on growth conditions of the year. In particular, the RUE value for 4 wheat varieties in one season differed significantly but in the next season it was the same for 3 varieties [12]. Recently we have shown that influence of the genotype on the winter wheat canopy RUE during the reproductive period was stronger, than the effect of foliar treatments by micronutrient complex that included 7 trace elements, and its mixture with carbamide [11].

Most of the studies on the RUE differences among wheat varieties were conducted during the reproductive period of development, while the number of such studies for the pre-anthesis period is scarce. In particular, the increase in pre-anthesis RUE associated with yield improvement was shown in mentioned above studies for United Kingdom [14] and Australian wheat varieties [15]. It was suggested that RUE at the period before anthesis can affect the number of grains per land area. Higher growth rate at preanthesis stage associated with grain yield progress was reported for new high-yielding lines developed in southwestern Japan comparing with commercial wheat cultivars [17].

The aim of this work was to evaluate the efficiency of solar energy convertion into biomass in Ukrainian wheat varieties during the pre-anthesis growth period in order to dissect the physiological basics of high productivity.

\section{Materials and methods}

The studies of the relationship between radiation use efficiency during the pre-anthesis period and grain productivity of winter wheat varieties were conducted during 2017-2018 and 2018-2019. The field experiments were located at Institute of Plant Physiology and Genetics, National Academy of Sciences of Ukraine (IPPG NASU) experimental farm (Hlevakha, Kyiv Region, $50^{\circ} 16^{\prime} \mathrm{N}, 30^{\circ} 19^{\prime} \mathrm{E}$ ) under natural rainfed conditions. The soil was podzolic loam.

There were studied 6 varieties of bread winter wheat (Triticum aestivum L.) originated from the IPPG. Variety Smuhlianka is widely used high-yielding variety released in 2004, while the others 5 varieties Hospodarka, Kyivska 17, Pochaina, Krasnopilka and Poradnytsia are more recently released (2017-2018).

All varieties were sown in the third decade of September at sowing density of 5.5-6 million seeds per hectare in plots of $10 \mathrm{~m}^{2}(1.5 \times 6.67 \mathrm{~m})$ in 4 replications. Field management followed local practicies [18]. In total, the plots were fertilized with $145 \mathrm{~kg}$ of nitrogen and $90 \mathrm{~kg}$ of phosphorus 
and potassium per hectare. In autumn, $\mathrm{N}_{90} \mathrm{P}_{90} \mathrm{~K}_{90}$ was applied under presow ploughing. Additional $\mathrm{N}$ fertilization (urea) was applied on frozen ground in spring and at booting stage (GS 40-42). Herbicides were used in autumn (4th leaf unfolded, GS 21-22) and in spring (stem elongation, GS 35-39), fungicide at stem elongation (GS 35-39), insecticide at ear emergence (GS 54-56).

During the period of plants spring-summer vegetation in the growing season of both 2017/2018 and 2018/2019, the air temperature exceeded the corresponding values of the climatic norm (Table 1). Actual meteorological data were taken from meteorological station located close to the experimental field [19]. The largest difference in the average monthly air temperature $\left(3.8\right.$ and $\left.3.3^{\circ} \mathrm{C}\right)$ in 2018 was observed in April and May, while in $2019\left(5.0^{\circ} \mathrm{C}\right)$ in June. The spring of 2018 was characterized by arid conditions: in April the amount of precipitation was only $17 \%$ of the norm, in May $-68 \%$. Less than normal amount of precipitation was noted in 2019 in the month with the highest temperature - June.

The determination of phytometric parameters was carried out at 5 growing stages. The mean samples were formed from 20 randomly selected shoots in four replications. These shoots were divided into leaves, spikes and stems (including leaf sheaths). To determine the aboveground organs dry weight $5 \mathrm{~g}$ of leaves fresh weight and $10 \mathrm{~g}$ of spikes and stems of each variety were oven dried 2 hours at $105^{\circ} \mathrm{C}$ and then at $60{ }^{\circ} \mathrm{C}$ to constant weight. The yield was determined at full ripeness by the direct harvesting method in 4 replications. At full ripeness the grain yield components (grain weight from ear, grains number, weight of 1000 grains, harvest index) were determined using randomly selected 25 shoots. To determine the canopy density (shoots number per $1 \mathrm{~m}^{2}$ ), the total number of shoots on 2 half-meter transversal segments, randomly taken on each plot, was multiplied by a factor of 0.667 - to recalculate their number per $1 \mathrm{~m}^{2}$. The observations of growing stages by external morphological changes of the already formed organs were conducted every 3-4 days, during a period from stem elongation (GS 33) to full ripeness (GS 93) [20].

The leaf area of an individual shoot was determined using the weight method. The leaf area index, which characterizes the total area of green leaves of canopy, was calculated as the product of one shoot mean leaf area and their number per $\mathrm{m}^{2}$ of soil [21].

The values of total solar radiation per day were calculated from archival data from the Boris Sreznevsky Central Geophysical Observatory, measured by the wheather station near the test side, on the basis of 5 observations per day according to the formula [22]:

$$
\Sigma \mathrm{Q}=\tau_{1} \mathrm{Q}_{1} / 2+\left(\mathrm{Q}_{1} / 2+\mathrm{Q}_{2}+\mathrm{Q}_{3}+\mathrm{Q}_{4}+\mathrm{Q}_{5} / 2\right) \times 180+\tau_{2} \mathrm{Q}_{5} / 2
$$

where: $\Sigma \mathrm{Q}-$ total solar radiation per day, $\mathrm{J} / \mathrm{m}^{2} ; \mathrm{Q}_{1}-\mathrm{Q}_{5}-$ the total radiation intensity in the $1-5$ th observation period; $\tau_{1}-$ the time interval between sunrise and the first observation period; $\tau_{2}-$ the time interval between sunset and the last observation period.

The total radiation for a certain period of vegetation was calculated by adding its daily amounts for this period. Since crops usually absorb about 
$90 \%$ of PAR, and transmit about $50 \%$ of the near infrared radiation $(\lambda>$ $700 \mathrm{~nm}$ ), the conversion factor from total into photosynthetically active radiation was taken to be 0.487 [23].

The RUE or the efficiency of photosynthetic energy conversion into biomass was determined as the ratio of biomass formed during certain growing period to the amount of PAR absorbed by canopy for the same period [1]:

$$
\mathrm{RUE}=\left(\mathrm{M}_{\mathrm{i}}-\mathrm{M}_{\mathrm{k}}\right) / \Sigma \mathrm{PAR}_{\mathrm{i}-\mathrm{k}},
$$

where: $M_{i}-M_{k}-$ the difference between the above-ground dry weight from $1 \mathrm{~m}^{2}$ for the period between the $\mathrm{i}-\mathrm{k}$ phases $\left(\mathrm{g} / \mathrm{m}^{2}\right) ; \Sigma \mathrm{PAR}_{\mathrm{i}-\mathrm{k}}-$ the total PAR value for the same period of time $\left(\mathrm{MJ} / \mathrm{m}^{2}\right)$.

All data obtained was subjected to statistical analysis using statistical software Programs of Microsoft Excel (2013) according to methods described by Dospekhov [24].The results are expressed as means and standard error $(\mathrm{m} \pm \mathrm{SE})$. Data were analysed by variance analysis and Tukey test at $5 \%$ probability level $(\mathrm{P}<0.05)$. Correlation analysis was performed using Pearson method.

\section{Results and discussion}

The photosynthetically active solar radiation use efficiency is largely determined by the amount of absorbed light and the growing stage of plant development. In turn, the absorption of solar energy depends on the assimilation surface area, which is characterized by the LAI.

The LAI of winter wheat crops during the period from stem elongation (GS 33) to anthesis (GS 65) was higher in 2019 than in 2018 (Fig. 1). LAI at stem elongation in the first of these years varied within $3.4-3.8 \mathrm{~m}^{2}$ of green leaves per $1 \mathrm{~m}^{2}$ of soil, in the second $-3.1-3.2 \mathrm{~m}^{2} / \mathrm{m}^{2}$, whereas at anthesis, respectively, $4.5-6.3$ and $3.7-5.4 \mathrm{~m}^{2} / \mathrm{m}^{2}$. The bigger assimilation surface area during the spring vegetation period of 2019 resulted from higher tillering due to better weather conditions than in 2018 (Table 1).

An analysis of different winter wheat varieties LAI dynamics suggests that, starting from the booting (GS 45), they can be divided into 2 groups: with higher LAI - Hospodarka, Kyivska 17 and Pochaina, and with smaller LAI - Krasnopilka, Smuhlianka and Poradnytsia. LAIs in the first group of varieties were by $15-30 \%$ higher than in the second

TABLE 1. Deviations of actual daily mean air temperature and monthly precipitation mean during April-July of 2018 and 2019 from the long-term (2018-2019) average values

\begin{tabular}{l|c|c|c|c}
\hline \multirow{2}{*}{ Year } & \multicolumn{4}{c}{ Month } \\
\cline { 2 - 5 } & April & May & June & July \\
\hline \multicolumn{5}{c}{ Temperature deviations, ${ }^{\circ} \mathrm{C}$} \\
2018 & \multicolumn{5}{c}{+3.3} & +2.0 & +0.9 \\
2019 & +3.8 & +1.5 & +5.0 & -0.7 \\
& +1.3 & 68 & 136 & 121 \\
2018 & 17 & Actual precipitation, $\%$ of long-term mean & 102 \\
2019 & 105 & 143 & 82 & \\
\hline
\end{tabular}



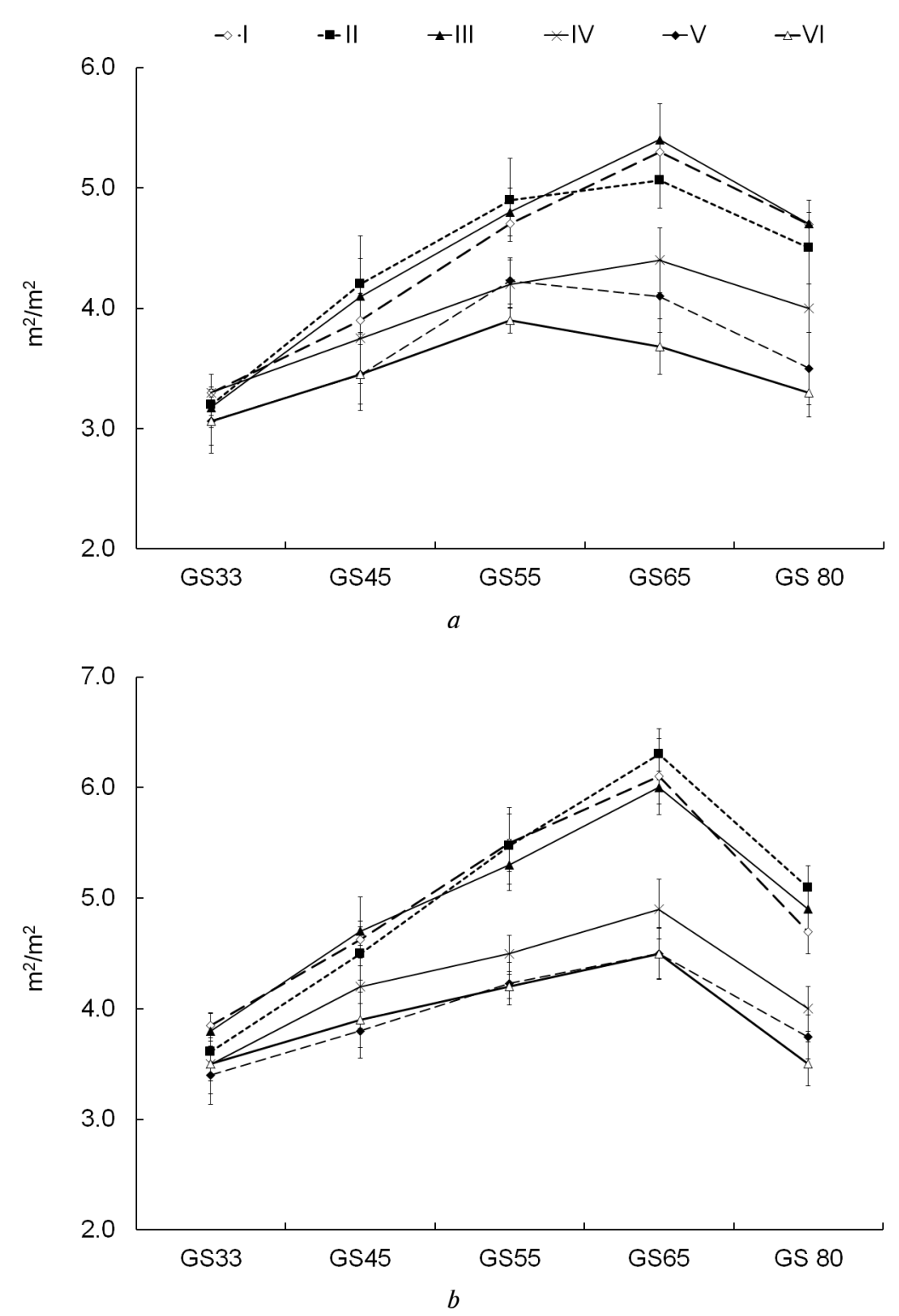

Fig. 1. Winter wheat varieties leaf area index dynamics during the period from stem elonga-

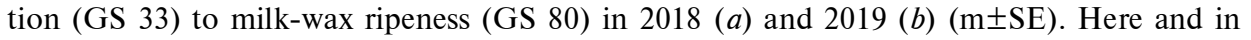
Fig. 2 varieties are designated as:

I - Hospodarka, II - Kyivska 17, III - Pochaina, IV - Krasnopilka, V - Smuhlianka, VI Poradnytsia

group (see Fig. 1) for approximately 3 weeks - from booting (GS 45) to anthesis (GS 65) (Table 2).

Dry weight of above-ground parts of plants growing on $1 \mathrm{~m}^{2}$ of soil at stem elongation stage in 2019 was by 15-36 \% higher than in 2018 (Fig. 2). At anthesis, above-ground dry weight in 4 varieties (Hospodarka, Krasnopilka, Smuhlianka and Poradnytsia) in 2019 were by $4-41 \%$ higher than in 2018, whilst in the other 2 varieties values of this parameter were close in both years. A distinctive feature of above-ground dry weight accumulation in varieties Hospodarka, Kyivska 17, Pochaina and Krasnopilka was 
G.O. PRIADKINA, O.O. STASIK, A.M. POLIOVYI et al.

\begin{tabular}{|c|c|c|c|c|}
\hline Variety & $\begin{array}{c}\text { Stem elongation } \\
\text { (GS 33) }\end{array}$ & $\begin{array}{l}\text { Booting } \\
\text { (GS 45) }\end{array}$ & $\begin{array}{l}\text { Ear emergence } \\
(\text { GS 55) }\end{array}$ & $\begin{array}{l}\text { Anthesis } \\
\text { (GS 65) }\end{array}$ \\
\hline \multicolumn{5}{|c|}{2018} \\
\hline Hospodarka & $26 / 04 / 18$ & $03 / 05 / 18$ & $16 / 05 / 18$ & $25 / 05 / 18$ \\
\hline Kyivska 17 & $26 / 04 / 18$ & $03 / 05 / 18$ & $16 / 05 / 18$ & $25 / 05 / 18$ \\
\hline Pochaina & $27 / 04 / 18$ & $04 / 05 / 18$ & $16 / 05 / 18$ & $26 / 05 / 18$ \\
\hline Krasnopilka & $27 / 04 / 18$ & $04 / 05 / 18$ & $16 / 05 / 18$ & $25 / 05 / 18$ \\
\hline Smuhlianka & $26 / 04 / 18$ & $03 / 05 / 18$ & $16 / 05 / 18$ & $25 / 05 / 18$ \\
\hline Poradnytsia & $26 / 04 / 18$ & $03 / 05 / 18$ & $16 / 05 / 18$ & $25 / 05 / 18$ \\
\hline \multicolumn{5}{|c|}{2019} \\
\hline Hospodarka & $29 / 04 / 19$ & 08/05/19 & $20 / 05 / 19$ & $28 / 05 / 19$ \\
\hline Kyivska 17 & $29 / 04 / 19$ & 08/05/19 & $20 / 05 / 19$ & $28 / 05 / 19$ \\
\hline Pochaina & $29 / 04 / 19$ & $08 / 05 / 19$ & $20 / 05 / 19$ & $29 / 05 / 19$ \\
\hline Krasnopilka & $29 / 04 / 19$ & $08 / 05 / 19$ & $20 / 05 / 19$ & $29 / 05 / 19$ \\
\hline Smuhlianka & $29 / 04 / 19$ & $08 / 05 / 19$ & $20 / 05 / 19$ & $28 / 05 / 19$ \\
\hline Poradnytsia & 29/04/19 & 08/05/19 & $20 / 05 / 19$ & $28 / 05 / 19$ \\
\hline
\end{tabular}

the high growth rate from ear emergence to anthesis: 19-28 in 2018 and $24-26 \mathrm{~g} /\left(\mathrm{m}^{2}\right.$ - day) in 2019 (see Fig. 2). The varieties Smuhlianka and Poradnytsia had lower growth rate, respectively $-12-20 \mathrm{~g} /\left(\mathrm{m}^{2} \cdot\right.$ day $)$. In the period from anthesis to milky-wax ripeness, the growth rate of aboveground parts remained higher in 3 varieties - Hospodarka, Kyivska 17 and Pochaina.

In total, accumulated solar radiation in April, May, and July 2019 was lower than in the corresponding months of 2018 due to the bigger, than in 2018, number of cloudy and rainy days (Table 3). In June 2019, during the grain formation period, on the contrary, the incoming of PAR was higher than in 2018.

The different quantity of PAR absorbed by crops during these years, as well as dry weight of above-ground parts of plants, were the main cause of changes in the efficiency of radiation conversion into biomass. The difference in the RUE was especially significant at the early stages of spring vegetation (in the period from stem elongation to booting): in 2019, it was 3-4 times higher than in 2018 (Fig. 3, $a, b$ ). The RUE in 2019 was also higher, than in 2018, during period from heading to anthesis due to better weather conditions in the spring of 2019. Despite higher total accumulated

TABLE 3. Monthly accumulated solar radiation from April to July, $M J / m^{2}$ (Data of the Boris Sreznevsky Central Geophysical Observatory)

\begin{tabular}{l|c|c|c|c}
\hline \multirow{2}{*}{ Year } & \multicolumn{5}{c}{ Month } \\
\cline { 2 - 5 } 2018 & April & May & June & July \\
2019 & 500 & 623 & 615 & 747 \\
& 450 & 501 & 719 & 502 \\
\hline
\end{tabular}



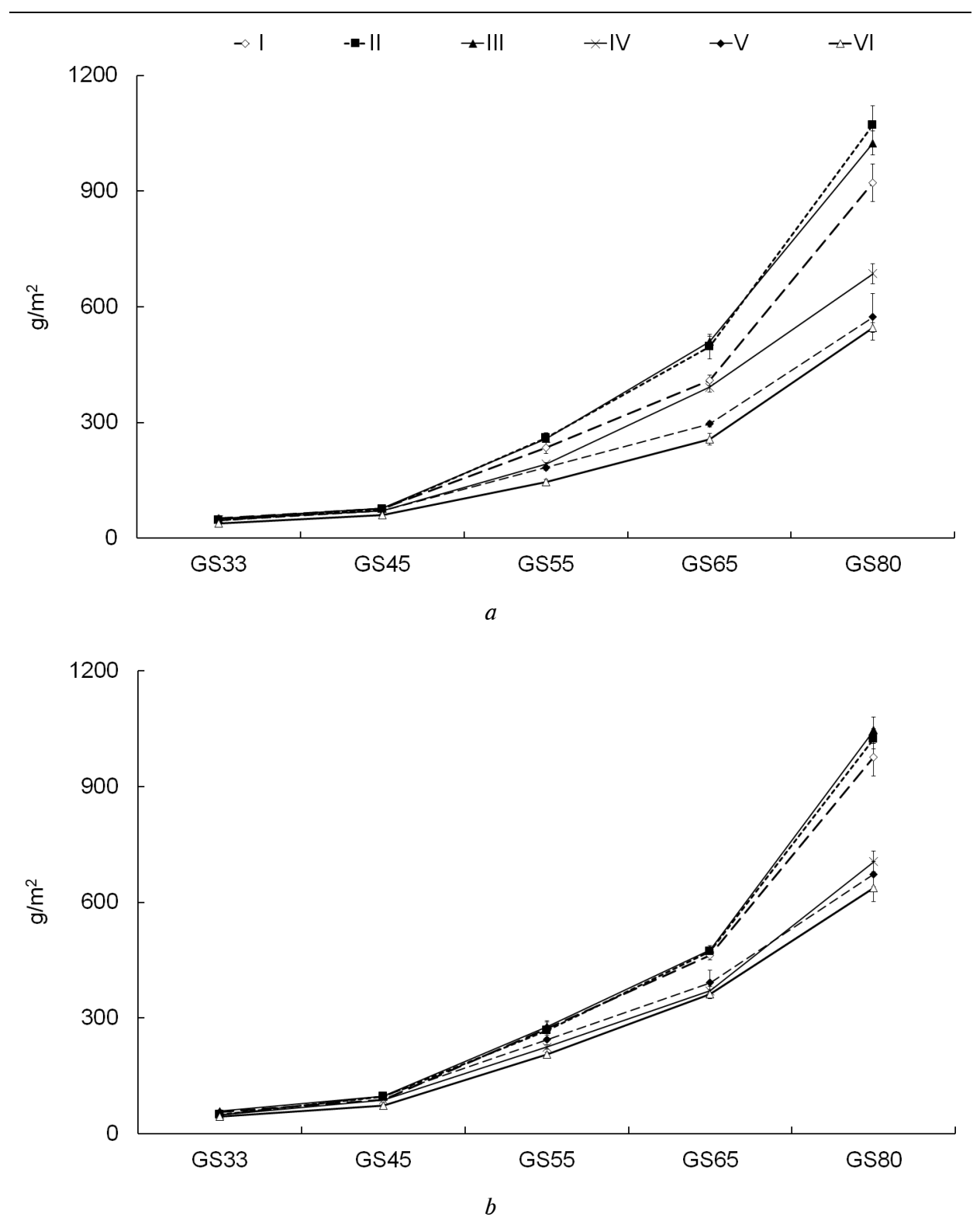

Fig. 2. Plants above-ground dry weight accumulation in winter wheat varieties during the period from stem elongation (GS 33) to milk-wax ripeness (GS 80) in 2018 (a) and 2019 (b) $(\mathrm{m} \pm \mathrm{SE})$

solar radiation during this period in 2018, higher temperature and less precipitation were the reason for the lower value of RUE.

In the early period of spring vegetation (stem elongation-booting) in 2018 and in 2019, the RUE between varieties did not differ significantly (Fig. 3). In the period of booting-heading, RUE in varieties Hospodarka, Kyivska 17 and Pochaina was higher for both years: $(1.49-1.86 \mathrm{~g} / \mathrm{MJ}$ in 2018 and $1.70-1.83 \mathrm{~g} / \mathrm{MJ}$ in 2019), than in other three varieties $(0.89-$ 1.14 and $1.31-1.45 \mathrm{~g} / \mathrm{MJ}$, respectively). During the period from heading to anthesis, RUE values were highest in the varieties Hospodarka, Kyivska 17, Pochaina and Krasnopilka in 2018 (1.87-2.71 g/MJ), whereas in 2019 - 

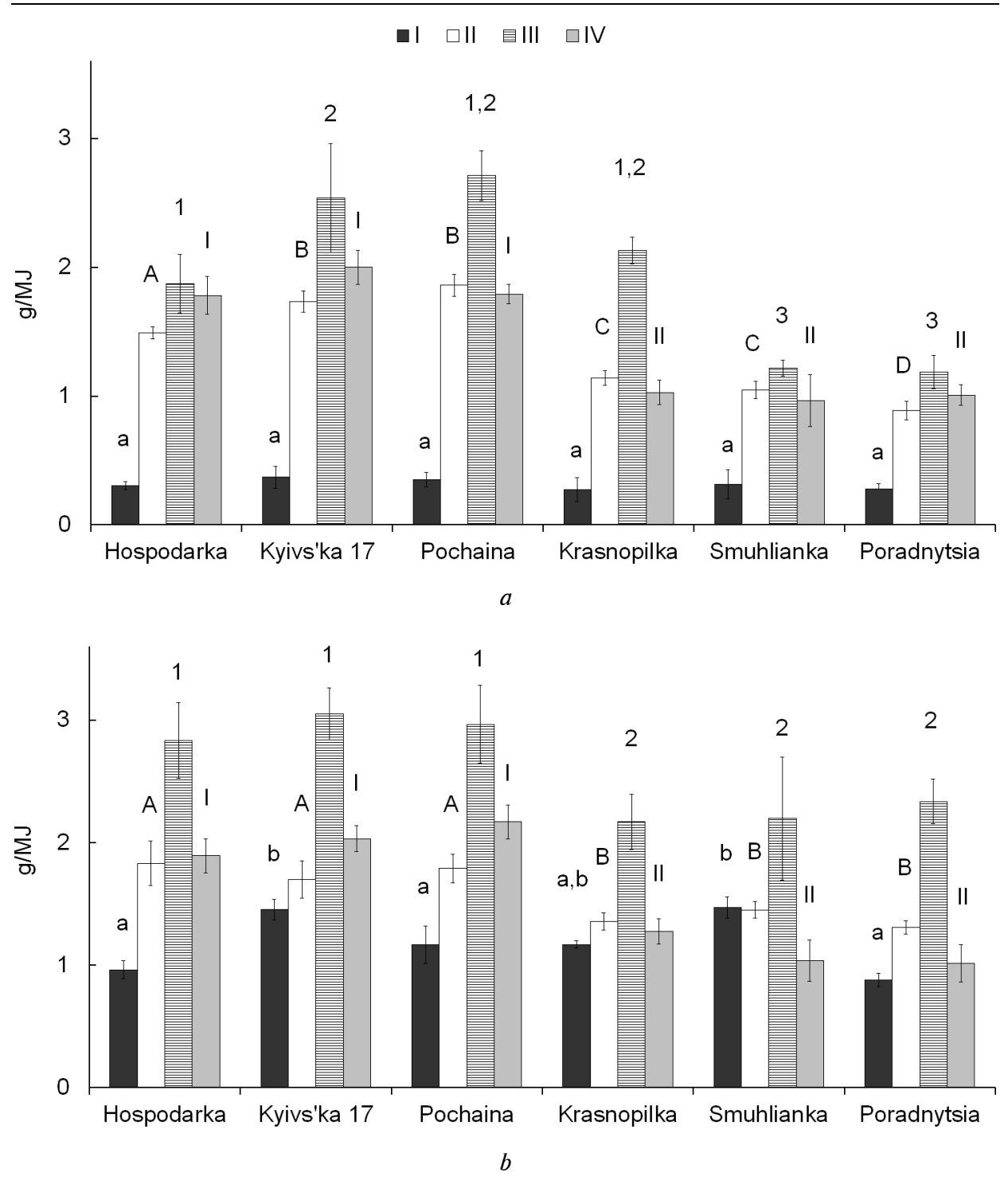

Fig. 3. Radiation use efficiency in winter wheat varieties in $2018(a)$ and $2019(b)(\mathrm{m} \pm \mathrm{SE})$ : I - stem elongation-booting (GS 33-45); II - booting-ear emergence (GS 45-55); III - ear emergence-anthesis (GS 55-65); IV - anthesis-milky-wax ripeness (GS 65-80); the values, indicated by the same letters or numbers, do not differ significantly between varieties in each of the years $(p \leq 0.05)$

only in the first three varieties $(2.83-3.05 \mathrm{~g} / \mathrm{MJ})$. The efficiency of energy conversion into biomass in winter wheat varieties Kyivska 17, Hospodarka and Pochaina during period anthesis-milk-wax ripeness, in both years significantly exceeded its value in the other 3 ones.

These three varieties had also higher grain yield in both years: $8.60-$ $8.72 \mathrm{t} / \mathrm{ha}$ in 2018 and 9.15-9.78 t/ha in 2019, while grain yield of the varieties Krasnopilka, Smuhlianka and Poradnytsia varied between $7.12-7.85$ and 7.85-8.48 t/ha, respectively (Fig. 4). It is worth noting that yield of winter wheat varieties in 2018 with limited rainfall during the period of reproductive organs formation (April-May) was lower than 2019, when water shortage was during the period of grain filling (June). The varieties 


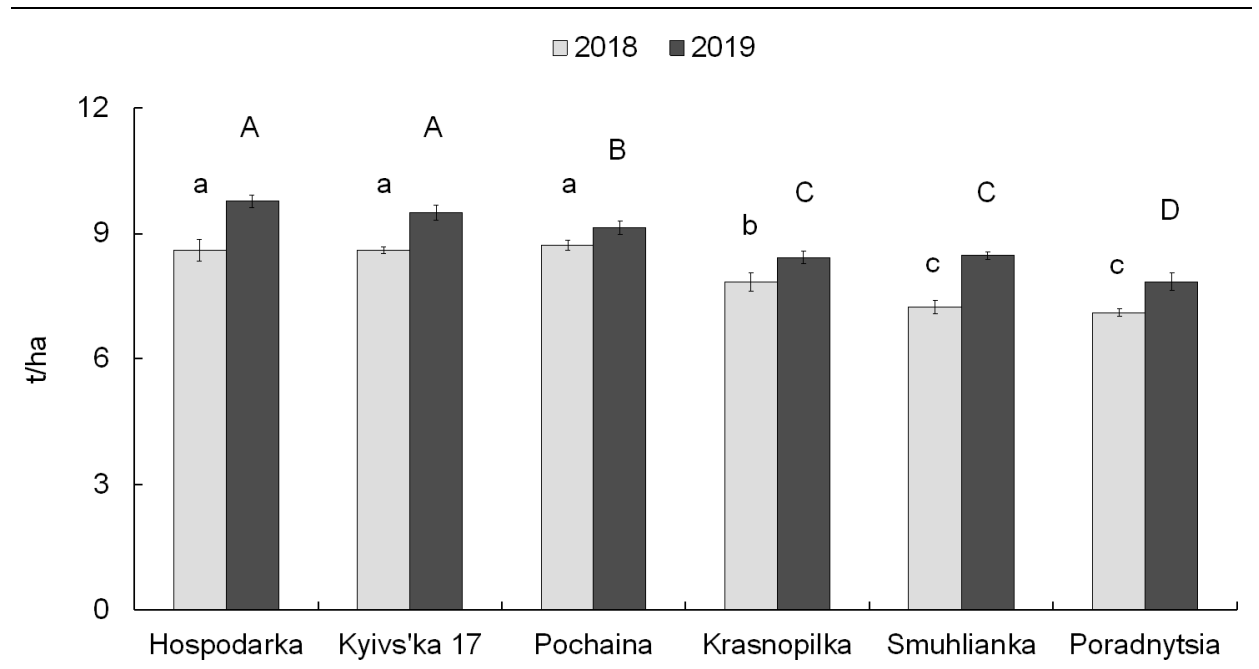

Fig. 4. Winter wheat varieties grain yield in 2018 and $2019(\mathrm{~m} \pm \mathrm{SE})$. Here and in Fig. 5 values, indicated by the same letters (lowercase - 2018, uppercase - 2019), do not differ significantly between the varieties; the difference between values in some years for each of the varieties is significant $(\mathrm{p} \leq 0.05)$

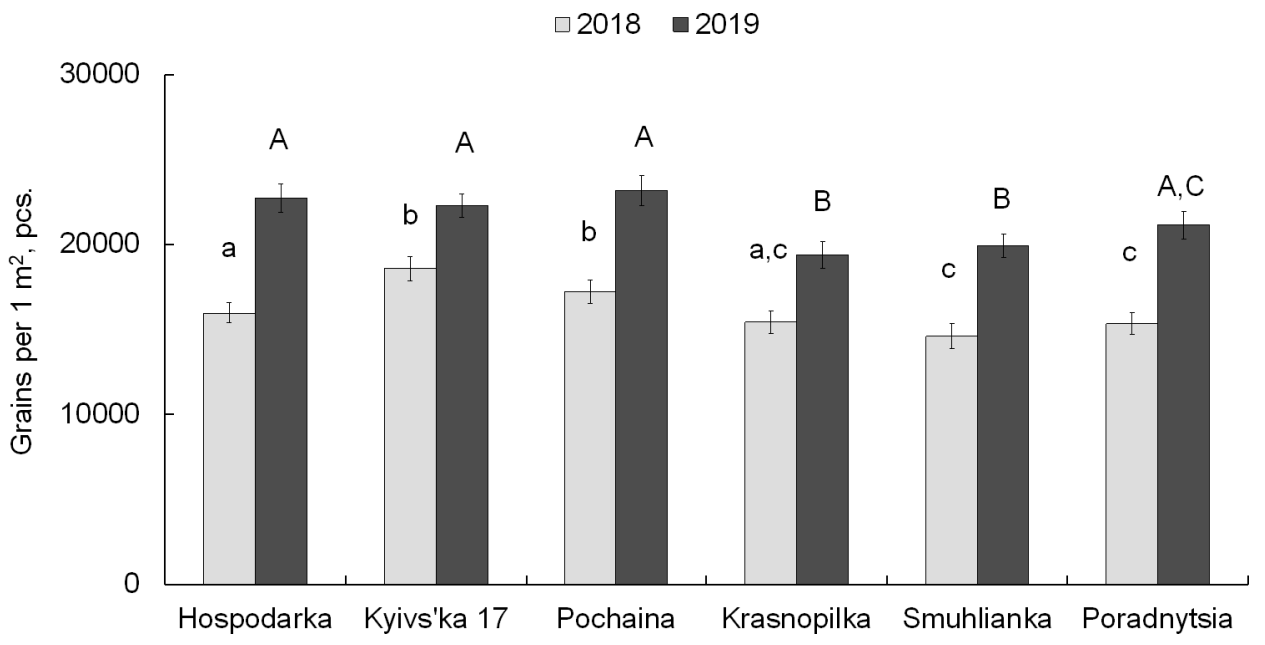

Fig. 5. Grain number per $1 \mathrm{~m}^{2}$ in years with drought conditions in different growth periods of winter wheat varieties $(\mathrm{m} \pm \mathrm{SE})$

with higher yield had a lager number of grains per square meter of soil than less-yielding ones (Fig. 5).

Higher RUE in more productive wheat varieties was reported in the literature. In particular, it was found that three modern high-productive wheat varieties growing in Bangladesh had higher efficiency of photosynthetic energy conversion into biomass for the period from 42 to 102 days after sowing $(0.80-0.94 \mathrm{~g} / \mathrm{MJ})$, than two less productive varieties $(0.60-$ $0.72 \mathrm{~g} / \mathrm{MJ}$ ) [25]. A positive correlation between winter wheat yield and RUE was also found for whole vegetation period [26], as well as for reproductive [11] and pre-anthesis growing periods [14]. A higher yield corresponded to bigger RUE values in winter wheat grown under dryland and irrigated conditions in the Southern Great Plains (USA) [27]. 
G.O. PRIADKINA, O.O. STASIK, A.M. POLIOVYI et al.

TABLE 4. Correlations between radiation use efficiency and the grain yield, and grain number per $1 \mathrm{~m}^{2}$

\begin{tabular}{lcc}
\hline \multirow{2}{*}{ Period } & \multicolumn{2}{c}{ Year } \\
\cline { 2 - 3 } & \multicolumn{1}{c}{ Correlation coefficient with grain yield } \\
\hline \multirow{2}{*}{ Stem elongation-booting } & $0.66 \pm 0.38$ & 2019 \\
Booting-ear emergence & $0.95 \pm 0.16^{*}$ & $0.19 \pm 0.49$ \\
Ear emergence-anthesis & $0.88 \pm 0.24^{*}$ & $0.94 \pm 0.17^{*}$ \\
Anthesis-milky-wax ripeness & $0.93 \pm 0.19^{*}$ & $0.82 \pm 0.28^{*}$ \\
\multicolumn{1}{c}{ Correlation coefficient with grain number per $1 \mathrm{~m}^{2}$} \\
Stem elongation-booting & $0.83 \pm 0.28^{*}$ & $0.87 \pm 0.25^{*}$ \\
Booting-ear emergence & $0.85 \pm 0.26^{*}$ & $0.22 \pm 0.49$ \\
Ear emergence-anthesis & $0.82 \pm 0.28^{*}$ & $0.86 \pm 0.25^{*}$ \\
Anthesis-milky-wax ripeness & $0.88 \pm 0.24^{*}$ & $0.93 \pm 0.18^{*}$ \\
& & $0.85 \pm 0.27^{*}$ \\
\hline
\end{tabular}

A significant positive correlations between RUE in specific periods of pre-anthesis growth and grain productivity were established for data obtained in both years, with the exception for period of the stem elongation-booting (Table 4). A close correlation between RUE during specific periods of pre-anthesis growth and grain productivity, which we found for different winter wheat varieties in various weather conditions, was related to noticeable genotypic differences in efficiency of energy conversion into biomass during this period.

Genotypic differences in RUE value for some growth periods have been noted other researchers, too. Thus, in high-yielding double haploid lines of spring wheat, the efficiency of light energy conversion into biomass during period from the beginning of tillering to full ripeness was higher, than in less productive local Chilean varieties $(4.8-5$ and $3.4-4.1 \mathrm{~g} / \mathrm{MJ}$, respectively) [28]. A significant difference in the solar radiation use efficiency over the period from stem elongation to anhtesis (GS 31-61) was revealed both among varieties of different height (tall and semi-dwarf varieties) and among semi-dwarf varieties [14]. An analysis of the efficiency of light energy conversion into biomass of 150 spring wheat varieties also showed significant differences between them during pre-anthesis and reproductive growth periods [29].

Thus, both our results and literature data, indicate that the greater efficiency of light energy conversion into biomass during the period before anthesis can contribute to the differences in the grain productivity between wheat varieties. Perhaps this may be because of larger grain number formed on soil area unit. Indeed, according to our two-year experiment, the greater RUE during the pre-anthesis period of plant development was accompanied by an increase in grain number per square meter (Fig. 6). A larger number of grains from $1 \mathrm{~m}^{2}$ in 2019 , compared with 2018, was due to the best spring weather conditions for the growth and development of wheat (see Table 1) that resulted in higher RUE at the early growing stages (see Fig. 3). 


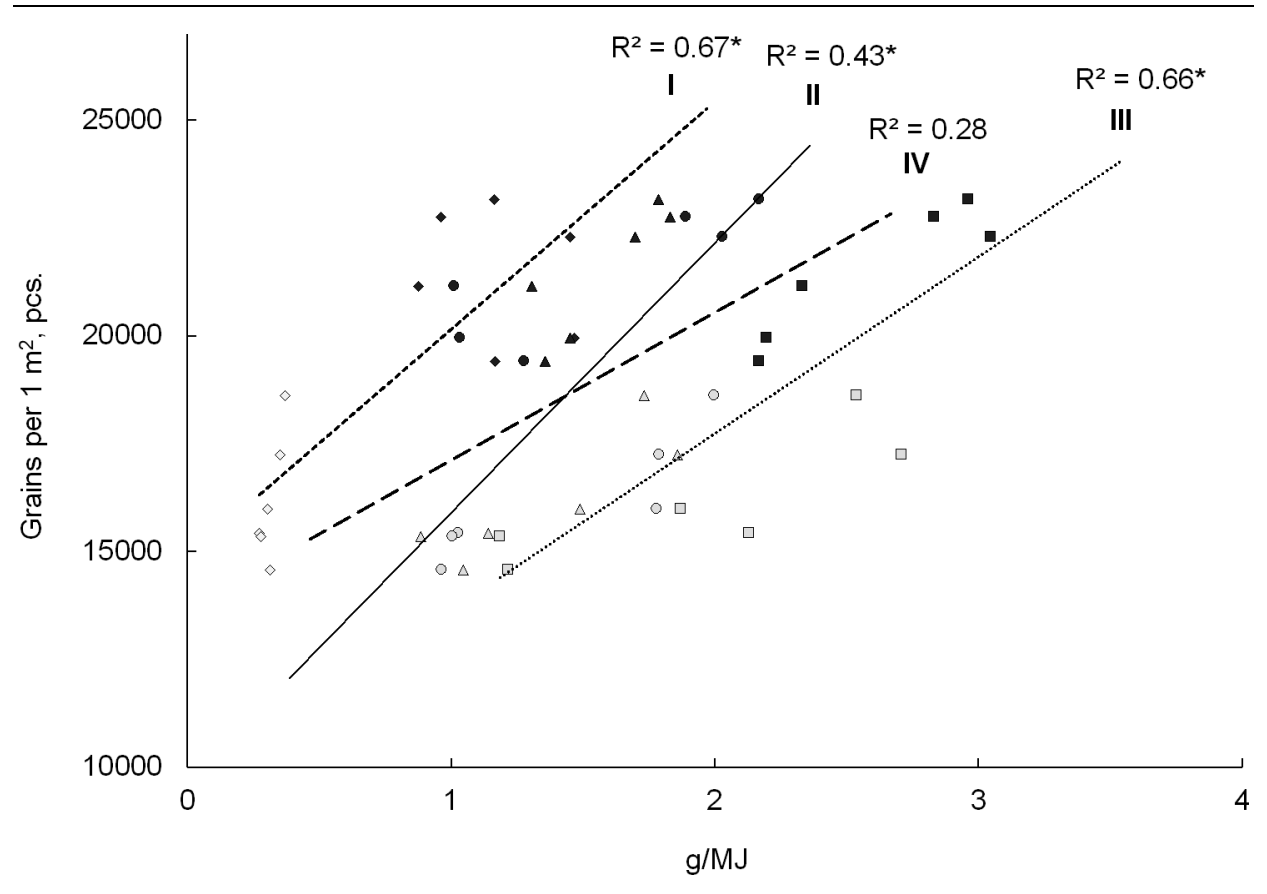

Fig. 6. Relationships between radiation use efficiency at some growth periods and grain number per $\mathrm{m}^{2}$ in a two-year field experiment (light marks -2018 , dark - 2019):

I - stem elongation-booting (GS 33-45); II - booting-ear emergence (GS 45-55); III - ear emergence-anthesis, (GS 55-65); IV - anthesis-milky-wax ripeness (GS 65-80); * correlation significant at 0.05 level

Varieties with greater RUE, obviously, can also be characterized by a bigger above-ground mass. An increase in dry weight of above-ground parts of wheat plants in the period before anthesis is considered as one of the sources of genetic increase in cereal crops yield in the UK [14]. In turn, the relationship between the dry weight of above-ground part and the number of grains is shown. In particular, it was found that in bread wheat and its relative spelt mapping populations contrasting in preanthesis biomass traits, the number of grains in the ear and their weight positively correlated with above-ground shoot biomass at flag leaf appearance (GS 39) [30]. It was suggested that recent genetic gains in grain yield have been based on a combination of improved growth rate in the preanthesis period, which has driven increase in grain number per square meter, and a larger source for grain filling through increase in stem soluble carbohydrate reserves [14]. The relationship between biomass and productivity confirms the identification of quantitative trait loci (QTL), which simultaneously affect them. In particular, QTLs linking biomass with productivity were established on wheat chromosomes 4B and 4D [31], as well as with some yield components on chromosomes 2B, 3A, 4A, 4B, 5A, 6A, and 7B [30]. Markers associated with RUE were also detected on chromosomes $5 \mathrm{~A}$ and $6 \mathrm{~A}$, including with RUE at the early stages of ontogenesis on 6A [29].

The problem of improvement of the efficiency of photosynthetic energy conversion into biomass is still debated in the literature [23, 29, 32] On the one hand, it can be associated with plants architectonics. Thus, higher RUE may have varieties with a smaller area and more erectoid flag 
leaves or with a reduced chlorophyll $a / b$ ratio due to a reduction in light absorption at the top of the canopy and, consequently, an increase in its penetration into the lower layers of the canopy, as well as through better adaptation of the lower leaves to low light intensity [23, 32]. But, at the same time, in 4 UK wheat varieties that did not differ in height and flag leaf attitude, RUE was not the same [14]. Hence, plant architectonics may not always be the main determining factor in improving RUE. In addition, varieties with a greater flag leaf specific dry weight and, respectively, with increased photosynthetic activity per leaf area unit, can also have greater efficiency of photosynthetic energy conversion into biomass [14].

More efficient photosynthetic carbon assimilation, electron transport and source-sink regulation may also contribute to higher RUE [32-34]. In particular, a positive correlation was found between the efficiency of light energy conversion into biomass and the leaf assimilation rate in some varieties, including spring wheat $[35,36]$. RUE increase can also be achieved by improving source-sink relationships, which can contribute to a rise in the outflow/utilization of photoassimilates, for example, for use in grain filling or temporary storage in stems [14, 37]

Thus, significant genotypic differences in the RUE among winter wheat varieties released in Ukraine were established in field experiment. A close relationship between the RUE during the pre-anthesis period and the grain productivity in winter wheat, revealed in two consecutive years with different weather conditions, indicates on importance of pre-anthesis biomass accumulation for yield determination, and that improving RUE in the pre-anthesis period will contibute to further increase in wheat grain productivity. The higher rate of above-ground biomass accumulation during period before anthesis associated with the rise in the grain number per $1 \mathrm{~m}^{2}$. Therefore, higher RUE during pre-anthesis growth may be considered as an important determinant of high wheat productivity. Although this parameter is difficult for phenotyping, the empirical search for genotypes with high RUE in different growth periods remains an important tool for selecting parental pairs to further increase of wheat grain productivity.

The publication contains the results of studies, conducted in the framework of the project, financed by the Cabinet of Ministers of Ukraine: «Supporting the development of priority trends of scientific studies» (KPKVK 6541230).

\section{REFERENCES}

1. Monteith, J.L. \& Moss, C.J. (1977). Climate and the Efficiency of Crop Production in Britain. Philos. T. R. Soc. B, 281, No. 980, pp. 277-294. https://doi.org/10.1098/ rstb. 1977.0140

2. Zhu, X.G., Long, S.P. \& Ort, D.R. (2008). What is the maximum efficiency with which photosynthesis can convert solar energy into biomass? Curr. Opin. Biotech., 19, No. 2, pp. 153-159. https://doi.org/10.1016/j.copbio.2008.02.004

3. Kiriziy, D.A., Stasik, O.O., Priadkina, G.O. \& Shadchina, T.M. (2014). Photosynthesis: $\mathrm{CO} 2$ assimilation and mechanisms of its regulation. Vol. 2. Kyiv: Logos [in Russian].

4. Tooming, H.G. (1984). Ecological principles of maximum crop productivity. Leningrad: Hydrometeoizdat [in Russian]. 
5. Duan, J., Wu, Y., Zhou, Y., Ren, X., Shao, Y., Feng, W., Zhu, Y., He, L. \& Guo, T. (2018). Approach to Higher Wheat Yield in the Huang-Huai Plain: Improving Postanthesis Productivity to Increase Harvest Index. Front Plant Sci., Oct 23, 9: 1457. https://doi.org/10.3389/fpls.2018.01457

6. Chen, X-X., Zhang, W., Liang, X-Y., Liu, Y-M., Xu, S.-J., Zhao, Q-Y., Du, Y-F., Zhang, L., Chen, X-P. \& Zou, C-Q. (2019). Physiological and developmental traits associated with the grain yield of winter wheat as affected by phosphorus fertilizer management. Sci. Rep., 9, No. 1, p. 16580. https://doi.org/10.1038/s41598-01953000-z

7. Austin, R.B. (1980). Physiological limitation to cereal yields and ways of reducing them by breeding. In: Hurd, R.C., Biscoe, P.V. \& Dennis, C. (Eds.). (pp. 3-19), Opportunities for Increasing Crop Yields. London: Pitman Publishing.

8. Morales, F., Ancin, M., Fakhet, D., Gonzalez-Torralba, J., Gamez, A.L., Seminario, A., Soba, D., Mariem, S.B., Garriga, M. \& Aranjuelo, I. (2020). Photosynthetic metabolism under stressful growth conditions as a bases for crop breeding and yield improvement. Plants, 9, 88. https://doi.org/10.3390/plants9010088

9. Slattery, R.A. \& Ort, D.R. (2015). Photosynthetic energy conversion efficiency: setting a baseline for gauging future improvements in important food and biofuel crops. Plant Physiol., 168, No. 2, pp. 383-392. https://doi.org/10.1104/pp.15.00066

10. Pradhan, S., Sehgal, V.K., Bandyopadhyay, K.K., Panigrahi, P., Parihar, C.M. \& Jat, S.L. (2018). Radiation interception, extinction coefficient and use efficiency of wheat crop at various irrigation and nitrogen levels in a semi-arid location. Indian J. Plant Physiol., 23, No. 3, pp. 416-425. https://doi.org/10.1007/s40502-018-0400-x

11. Priadkina, G.O., Stasik, O.O., Kapitanska, O.S., Yarmolska, O.E. \& Tsucrenko, N.V. (2019). Efficiency of use of photosynthetically active radiation in winter wheat crops. The Bull. Kharkiv Nationl. Agrarian Univ. Series Biology, 1, No. 46, pp. 23-34 [in Ukrainian]. https://doi.org/10.35550/vbio2019.01.023

12. Hussain, A., Chaudhry, R.M., Wajid, A., Ahmad, A., Ibrahim, M. \& Goheer, A.R. (2004). Influence of water stress on growth, yield and radiation use efficiency of various wheat cultivars. Int. J. Agric. Biol., 6, No. 6, pp. 1074-1079. 1560-8530/2004/06-6-10741079

13. Estrada-Campuzano, G., Slafer, G.A. \& Miralles, D.J. (2012). Differences in yield, biomass and their components between triticale and wheat grown under contrasting water and nitrogen environments. Field Crops Res., 128, pp. 167-179. https://doi.org/ 10.1016/j.fcr.2012.01.003

14. Shearman, V.J., Sylvester-Bradley, R., Scott, R.K. \& Foulkes, M.J. (2005). Physiological processes associated with wheat yield progress in the UK. Crop Sci., 45, pp. 175-185. https:/ doi.org/10.2135/cropsci2005.0175

15. Sadras, V.O., Lawson, C. \& Montoro, A. (2012). Photosynthetic traits in Australian wheat varieties released between 1958 and 2007. Field Crops Res., 134, pp. 19-29. https://doi.org/10.1016/j.fcr.2012.04.012

16. Acreche, M., Sanchez, M.J.A., Briceno-Felix, G. \& Slafer, G.A. (2009). Radiation interception and use efficiency as affected by breeding in Mediterranean wheat. Field Crops Res., 110, No. 2, pp. 91-97. httrs://doi.org/10.1016/j.fcr.2008.07.005

17. Okami, M., Matsunaka, H., Fujita, M., Nakamura, K. \& Nishio, Z. (2016). Analysis of yield-attributing traits for high-yielding wheat lines in southwestern Japan. Plant Prod. Sci., 19, No. 3, pp. 360-369. https://doi.org/10.1080/1343943X.2016.1151331

18. Morhun, V.V., Sanin, Ye.V., Shvartau, V.V. \& Omelianenko, O.A. (2011). 100 centners club. Winter wheat varieties of the Institute of Plant Physiology and Genetics of the National Academy of Sciences of Ukraine and Singenta protection system. Kyiv [in Ukrainian].

19. http://www.pogodaiklimat.ru/

20. Zadoks, J.C., Chang, T.T. \& Konzak C.F. (1974). A decimal code for the growth stages of cereals. Weed Res., 14, No. 6, pp. 415-421. https://doi.org/10.1111/j.13653180.1974.tb01084.X

21. Nichiporovich, A.A. (1963). About on ways to increase the productivity of photosynthesis in crops. In Photosyntesis and problems of plant productivity (pp. 5-36). Moscow: Izd-vo AN SSSR [in Russian]. 
22. Guide to hydrometeorological stations and posts on actinometric observations. (1973). Leningrad: Hydrometeoizdat [in Russian].

23. Zhu, X.G., Long, S.P. \& Ort, D.R. (2010). Improving photosynthetic efficiency for greater yield. Annu. Rev. Plant Biol., 61, pp. 235-261. https://doi.org/10.1146/annurevarplant-042809-112206

24. Dospehov, B.A. (1985). Field experiment methods. Moscow: Agropromizdat [in Russian].

25. Awal, M.A., Amin, M.R., Rhaman, M.S., Shelley, I.J. \& Rahman, M.Sh. (2017). Canopy characters and light-use efficiency of some modern wheat varieties in Bangladesh. J. Agric. Ecol. Res. Int., 11, No. 1, pp. 1-16. https://doi.org/10.9734/ JAERI/2017/31744

26. Tao, Z.Q., Wang, D.M., Ma, S.K., Yang, Y.S., Zhao, G.C. \& Chang, X.H. (2018). Light interception and radiation use efficiency response to tridimensional uniform sowing in winter wheat. J. Integr. Agric., 17, No. 3, pp. 566-578. https://doi.org/ 10.1016/S2095-3119(17)61715-5

27. Lollato, R.P. \& Edwards, J.T. (2015). Maximum attainable wheat yield and resource-use efficiency in the southern great plains. Crop Sci., 55, No. 6, pp. 2863-2876. https:// doi.org/10.2135/cropsci2015.04.0215

28. Bustos, D.V., Hasan, A.K., Reynolds, M.P. \& Calderini, D.F. (2013). Combining high grain number and weight through a DH-population to improve grain yield potential of wheat in high-yielding environments. Field Crops Res., 145, pp. 106-115. https:// doi.org/10.1016/j.fcr.2013.01.15

29. Molero, G., Joynson, R., Pinera-Chavez, F.J., Gardiner, L.-J., Rivera-Amado, C., Hall, A. \& Reynolds, M.P. (2019). Elucidating the genetic basis of biomass accumulation and radiation use efficiency in spring wheat and its role in yield potential. Plant Biotechnol. J., 17, No. 7, pp. 1276-1288. https://doi.org/10.1111/pbi.13052

30. Xie, Q., Mayes, S. \& Sparkes, D.L. (2016). Preanthesis biomass accumulation of plant and plant organs defines yield components in wheat. Eur. J. Agron., 81, pp. 15-26. https://doi./10.1016/j.eja.2016.08.007

31. Li, Z.K., Jiang, X.L., Peng, T., Shi, C.L., Han, S.X., Tian, B., Zhu Z.L. \& Tian, J.C. (2014). Mapping quantitative trait loci with additive effects and additive $\mathrm{x}$ additive epistatic interactions for biomass yield, grain yield, and straw yield using a doubled haploid population of wheat (Triticum aestivum L.). Gen. Molec. Res., 13, No. 1, pp. 14121424. https://doi.org/10.4238/2014.February.28.14

32. Furbank, R.T., Sharwood, R., Estavillo, G.M., Silva-Perez,V. \& Condon, A.G. (2020). Photons to food: genetic improvement of cereal crop photosynthesis. J. Exp. Bot., 71, pp. 2226-2238. https://doi.org/10.1093/jxb/eraa077

33. Weber, A.P.M. \& Bar-Even, A. (2019). Update: Improving the efficiency of photosynthetic carbon reactions. Plant Physiol., 179, pp. 803-812. https://doi.org/10.1104/ pp. 18.01521

34. Simkin, A.J., Patricia E. Lopez-Calcagno, P.E. \& Raines, C.A. (2019). Feeding the world: improving photosynthetic efficiency for sustainable crop production. J. Exp. Bot., 70, pp. 1119-1140. https://doi.org/10.1093/jxb/ery445

35. Reynolds, M.P., Pellegrineschi A. \& Scovmand, V. (2005). Sink limitation to yield and biomass: a summary of some investigations in spring wheat. Ann. Appl. Biol., 146, No. 1, pp. 39-49. https://doi.org/10.1111/j.1744-7348.2005.03100.x

36. Cabrera-Bosquet, L., Fournier, C., Brichet, N., Welcker, C., Suard, B. \& Tardieu, F. (2016). High-throughput estimation of incident light, light interception and radiation-use efficiency of thousands of plants in a phenotyping platform. New Phytol., 212, No. 1, pp. 269-281. https://doi.org/10.1111/nph.14027

37. Paul, M.J., Watson, A. \& Griffiths, C.A. (2020). Linking fundamental science to crop improvement through understanding source and sink traits and their integration for yield enhancement. J. Exp. Bot., 71, pp. 2270-2280. https://doi.org/10.1093/ jxb/erz480

Received 28.04.2020 


\title{
ЕФЕКТИВНІСТЬ ВИКОРИСТАННЯ РАДІАЦІІІ ПОСІВВМИ ОЗИМОЇ ПШЕНИЦІ В ПЕРІОД ВЕГЕТАТИВНОГО РОСТУ
}

\author{
Г.О. Прядкіна ${ }^{1}$, О.О. Стасик', А.М. Польовийㄹ, О.С. Ярмольська ${ }^{2}$, К. Кузмова
}

${ }^{1}$ Інститут фізіології рослин і генетики Національної академії наук України 03022 Київ, вул. Васильківська, 31/17, Україна

${ }^{2}$ Одеський національний екологічний університет

65016 Одеса, вул. Львівська, 15, Україна

${ }^{3}$ Аграрний університет

4000 Пловдив, просп. Менделєєва, 12, Болгарія

e-mail: galpryadk@gmail.com

Вивчали взаємозв’язок між ефективністю використання фотосинтетично активної радіації у вегетативний період онтогенезу і врожайністю озимої пшениці в польових експериментах у роки з посушливими погодними умовами (2018 p. - у період закладання репродуктивних органів, 2019 р. - у період наливу зерна). Дослідження проводили на 6 сортах м'якої озимої пшениці (Triticum aestivum L.), створених в Їнституті фізіології рослин і генетики НАН України. Сорт Смуглянка - відомий високоврожайний сорт, зареєстрований у 2004 р., решта 5 сортів - Господарка, Київська 17, Почайна, Краснопілка і Порадниця - новітньої селекції (2017-2018рр.). Встановлено, що, починаючи з фази виходу в трубку (GS 45), сорти можна розділити на 2 групи за листковим індексом: у сортів Господарка, Київська 17 і Почайна він був на 15-30\% вищий, ніж у сортів Краснопілка, Смуглянка та Порадниця. У період від цвітіння до молочно-воскової стиглості швидкість наростання маси сухої речовини у трьох перших сортів також була вища, ніж у трьох останніх. За ефективністю використання сонячної радіації в ранній період весняної вегетації (подовження стебла-вихід у трубку) сорти різнилися незначно, тоді як протягом періоду вихід у трубку-колосіння, а також цвітіння-молочно-воскова стиглість у сортів Господарка, Київська та Почайна цей показник достовірно перевищував значення у трьох інших сортів. Перші три сорти відрізнялися і вищим урожаєм зерна в обидва роки: 8,60-8,72 т/га в 2018 р. і 9,15-9,78 т/га в 2019 р., тоді як у сортів Краснопілка, Смуглянка та Порадниця він коливався відповідно в межах 7,12-7,85 і 7,85-8,48 т/га. Виявлено позитивну кореляцію між ефективністю використання радіації в окремі періоди вегетативного роз-

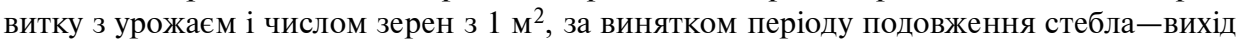
у трубку. Вища ефективність перетворення світлової енергії в біомасу в період до цвітіння сприяє збільшенню зернової продуктивності пшениці, що пов'язано з пришвидшенням накопичення надземної біомаси в період до цвітіння і більшою кількістю зерен на 1 м $^{2}$ грунту. Ці дані підтверджують припущення, що високий показник ефективності використання радіації в період вегетативного росту є важливим чинником високої продуктивності пшениці і може бути використаний як потенційний критерій для селекції пшениці на високу продуктивність.

Ключові слова: Triticum aestivum L., ефективність використання сонячної радіації, продуктивність, накопичення біомаси до цвітіння. 